\title{
Reform and Innovation of Integrated Curriculum System of Ideological and Political Courses
}

\author{
Zhong Guo
}

\author{
Shandong Technology and Business University, Yantai, China \\ ${ }^{*}$ Corresponding author. Email:912768810@qq.com
}

\begin{abstract}
On the one hand, the ideological and political courses has received unprecedented attention, and some new content has been constantly added to the ideological and political technology and economy. On the other hand, under the strict limit of the total class hours in the four years of college, the phenomenon of striving for class hours of each course is becoming more and more serious. How to give good ideological and political classes and achieve training goals is an important issue in front of us. According to the interdependence and mutual support of ideological and political courses, this paper integrates these two courses and eliminates the repeated content by modern network information technology, to better solve the relationship between theory and practice and better reflect the interdependence and mutual support of each course.
\end{abstract}

Keywords: Model exploring the integration of political courses, the reform of ideological, political courses.

\section{INTRODUCTION}

General Secretary Jin ping Xi speech at the National Conference on Ideological and Political Work in Colleges and Universities pointed out that "the fundamental problem of ideological and political work in universities is the fundamental problem of what kind of people universities cultivate, how to cultivate people and who to cultivate people for" [1]. College Ideological and Political Theory Course, The fundamental task is, Through the study of the courses of the Basic Principles of Marxism, the Outline of Modern Chinese History, Mao Zedong Thought and the Theory of Socialism with Chinese Characteristics, Ideological and Moral Cultivation and Legal Foundation and Situation and Policy, Guide students to closely combine political, economic, cultural and personal related experiences, Inquiry into learning and social practice, Understanding of Marxism, Mao Zedong Thought And the basic views and methods of the theory of socialism with Chinese characteristics, improve the ability to participate in modern social life, make students master, recognize and support Marxism, socialism and Communist Party, enhance their belief, Marxism, trust, faith, confidence and trust; form correct world outlook, outlook on life and values, lay the foundation for lifelong development. Comrade Jinping $\mathrm{Xi}$ emphasized "promoting the reform and innovation and constantly enhance the ideological, theoretical and affinity and pertinence of ideological and political courses" [2]. As teachers of ideological and political courses in universities, they must deeply understand the extreme importance of ideological and political curriculum teaching, and actively promote the reform, construction and innovation of the integration of ideological and political curriculum curriculum system.

\section{THE PROBLEMS EXISTING IN THE IDEOLOGICAL AND POLITICAL COURSE TEACHING}

\subsection{The School is not Enough of the Ideological and Political Courses, and it is Difficult to Implement Relevant Policies}

Lack of perfect system guarantee and resource allocation, for ideological and political class teaching system construction funds and teaching facilities is relatively low, education departments at all levels and university leaders at all levels, there is a misunderstanding: think ideological and political class as long as the teacher speak, the teacher prepared, a lot of increase teaching can, do not need equipment and funds, in fact, this is completely wrong, they understand the ideological and political class as is a simple preaching process. Ideological and political course is a systematic curriculum system, to let students to finally 
understand, understand and understand, and achieve our education purpose: let students to Chinese marxism, socialism with Chinese characteristics and the communist Party of China faith, faith, faith, confidence and trust, must let students become the main body of learning, learning, actively, so as to gradually form the correct world outlook, outlook on life and values. Then we have to provide evidence of our preaching from multiple perspectives to examine, explore and experience some important events, important red genes, important people and surrounding resources that require a lot of money and platform building.

\subsection{Teaching Model is Dominant}

In most colleges of higher learning, the number of ideological and political courses is more than 100 , each teacher has overloaded teaching workload, much teaching content, tight time becomes a practical problem, and teachers are lack of skill. Therefore, in the teaching content, teaching subject, teaching means, teaching management and other aspects, teachers passive to incullling classroom. The leader and subject of classroom teaching are unified in the role of teachers. In a big class, in addition to the students answering several fixed questions, they did not really participate in the classroom teaching. In the long run, the classroom would lose different voices and become a speech [4]. Moreover, some teachers themselves do not be pioneering and enterprising, some teachers speak a class for a few years or decades, annually with the same teaching plan changes very little, only pay attention to the knowledge points and theory teaching, only talk about their own, do not consider the students ' feelings.

\subsection{Ideological and Political Curriculum System is Imperfect, and the Unreasonable Curriculum Design}

Ideological and political course is the public basic general course of institutions of higher learning. General course is to cultivate students 'ability to understand the world, improve students' self-cultivation, master the living ability to adapt to the society, and help students gradually form a correct world outlook, outlook on life and values. At present, the ideological and political courses of higher learning are mainly set up by teaching knowledge points, with too much emphasis on the concept and their own theoretical logic. We should be clear that we are not training Marxist theorists, historians and ideological and political teachers. The school innovates the curriculum system of ideological and political science, lacks effective curriculum design, and lacks insufficient integration of curriculum content. Teachers often only pay attention to the results, the exam only pay attention to how much students recite, ignore the evaluation of the teaching process, which makes it too utilitarian and affects the values of college students. Students cannot play the role of the main subject in the ideological and political education classroom, and they are difficult to achieve the education goals when they pay too much attention to theoretical education. At the same time, most of the curriculum settings are not scientific enough, and the teaching content lacks a certain substantive [5].

\subsection{Uneven Use of Teaching Space Outside Teacher Classroom}

The development of the Internet makes teaching possible to extend beyond the classroom. MOOC class, practical classroom and virtual VR classroom emerged at the historic moment, creating a huge virtual teaching space outside the classroom teaching, enriching the classroom teaching content [4]. However, due to the huge differences between the ideological and political class teachers themselves to master the modern information technology, except for some young teachers, almost all the old teachers and some middle-aged teachers are the small white of modern information technology. The construction and application of virtual teaching cannot be popularized and enforced. Moreover, some teachers regard the use of modern science and technology as a means to reduce their own teaching work, rather than improving the teaching effect and achieving our training goals. For example, some teachers introduce MOOC in their own class, and teachers and students watch the MOOC together, almost without participated in the teacher. $\mathrm{He}$ (she) has completely become a "student" and a defender of classroom discipline! In addition, teachers take the way of online independent learning, imagine if the students of ideological and political learning has not cultivated interest, no initiative to learn and self-control ability, then network teaching will only be a mere formality, and most colleges and universities did not combine with the social environment, put forward unified requirements for teachers, so can not guarantee the quality of teaching is consistent.

\subsection{The Construction of Ideological and Political Class Teachers Lacks Systematicness and Sustainability, and the Overall Level of Teachers is not High}

Due to the long time that our national governments and colleges and universities have not guided and attached enough importance to ideological and political theory, the professional level of ideological and political class teachers is generally not high. Especially in recent years, the state has paid more attention to the university ideological and political theory courses, and made a series of specific requirements, which have greatly improved the status of ideological and political courses, such as the increase of ideological and political courses, the rigid provisions on the comparison between teachers 
and college students, and the improvement of the treatment of ideological and political course teachers. More intensified the serious shortage of ideological and political teachers, some colleges and universities in order to achieve the national ideological and political teachers and college students than rigid requirements, some counselors, party and government management staff when political teachers, the ideological and political teachers have a considerable part of their major has nothing to do with ideological and political theory, some colleges and political teachers their major has nothing to do with the majority, ideological and political teachers level further decline, the author think this is also very not serious!

\subsection{All Ideological and Political Courses did not Integrate and Effectively Form Joint Forces, and did not Play the Role of Ideological and Political Courses}

First, the curriculum is divided, the Marxist College of various departments (Teaching and Research Office) under the institutions of higher learning are basically divided according to the courses taught by teachers, such as "Mao Summary Teaching and Research Office", "Situation and Policy Teaching and Research Office" and so on. Because most teachers belong to the different a class for years or even decades, and other ideological and political courses are never astringent, how can the horizontal and horizontal integration in teaching? Not to mention those who are this major is not the direction of ideological and political class teachers, they also learn to sell now, that also talk about the integration of vertical and horizontal integration! Such teaching methods can not reflect the interdependence between ideological and political courses and the overall organic, and cannot achieve the purpose of education.

\section{SECOND. TEACHING REFORM MEASURES AND PATHS OF IDEOLOGICAL AND POLITICAL COURSES}

\subsection{Strengthen the Investment in Ideological and Political Course Construction, and Improve the Platform Construction}

The resources of college ideological and political courses are not only reflected in the ideological and political textbooks and the cultural reserve of teachers, There are also some extracurricular practice activities, which can also provide students with rich ideological and political teaching resources, Ideological and political practice education is not only to train students and improve their comprehensive quality, [6] to integrate ideological and political teaching resources in practical activities and ideological and political teaching resources in the classroom, So the schools must unite with the government, the society, Build a red education base and a patriotic education base, Contact nursing homes, welfare homes to cultivate noble moral character and love of labor virtues, Actively organize and participate in local large social activities and public welfare activities as volunteers, Cultivate students ' comprehensive ability and quality and the noble sentiment of love family, society and country, Return political education to the "living world". Some require certain input from schools, the government and the society. Like other courses offered by universities, the construction of ideological and political courses is also inseparable from information science, network and platform construction. With the rapid development of China's economic and cultural undertakings, celebrating the 100th anniversary of the founding of the Communist Party of China, in addition to mass open online courses like MOOC, governments at all levels have built many online libraries, online museums, online red education base APP platform, learning power learning platform, and various film and television materials.China needs scientists, but also more needs scientists like Longping Yuan and Nanshan Zhong.

\subsection{Using Information Technology, Optimize the Teaching Mode and Enrich the Teaching Content}

The use of information technology, network and big data to obtain knowledge caters to students ' preferences, broaden the ideological and political teaching field of colleges and universities, optimize the teaching mode, and enrich the teaching content.

First, the national investment to strengthen the construction of information infrastructure, universities have established exclusive campus network system, open library management system, education intelligent software increasingly popularize the foundation for the full implementation of the concept of "Internet + education" laid the [8], then the service terminal mobile provides the participation of teachers and students. In order to change the dominant situation of the indoctrination classroom teaching mode dominated by teachers, we must open the practice link of ideological and political courses, and closely rely on the red education bases and patriotic education bases, nursing homes, welfare homes are unable to meet the teaching practice link of ideological and political courses. Modern information technology and the Internet are gradually changing the traditional ideological and political education system and the way of ideological and political course practice. Ideological and political class teachers should follow and use the virtual space carried by the network media to carry out ideological and political teaching reform, build the teaching mode of "Internet + ideological and political class + extracurricular practice", make the network platform 
become an important platform for ideological and political course teaching, and form complementary online and offline teaching. Enrich extracurricular teaching, expand a variety of teaching methods, enrich the education carrier. The practical teaching mode of ideological and political courses in universities realizes the purpose of making students return from theoretical knowledge to life practice, while the Internet information technology makes the ideological and political course practical teaching mode can be realized online. For example, We can visit the teaching scenes of red education bases, revolutionary education bases, history museums and other field scenes that are difficult to show in the traditional classroom, Realize the Ultra HD panoramic live broadcast, Even even interact with docnarrator, You can also use the "college MOOC", "Tencent Classroom", "Kuaishou" and other platforms, Make online ideological and political teaching forms such as "micro class", "micro film", "cloud class", "flip classroom" and so on, Carry out diversity, sharing and interactive network teaching, To provide students with the ideological and political education content that integrates the ideological and educational nature of the Times, Realize the ideological and political class "into the ears" "into the brain" "into the heart", Realize the effective connection between the supply side and the demand side. Teachers can also through the network platform second classroom activity data data, real-time, dynamic, monitoring the behavior of college students, grasp the college students ' doubts, social hot spots, teaching blind spots, management difficulties and ideological attitude, behavior characteristics, accurately grasp the needs of college students, grasp the education opportunity, find problems in time, targeted teaching. The decentralized data resources will be analyzed, summarized and integrated, "transported" all kinds of resources in different places, and extend the breadth and depth of ideological and political education [12].

In order to make full use of network information resources, as the ideological and political teaching teachers, for network information resources to establish a serious attitude and actively learn the relevant knowledge and skills of big data application, according to their own teaching experience and knowledge to solve the problems in the process of the application of network information resources, and constantly improve the network information resources and ideological and political courses teaching. According to the characteristics of modern teaching, the construction of teachers, not only "old with the new", but also "new with the old".

\subsection{Improve Teachers ' Own Political Awareness and Professional Level}

Education plan, teacher-oriented. General Secretary Jinping $\mathrm{Xi}$ has stressed that "The key to running the ideological and political theory course lies in teachers." For a long time, due to the neglect of Party organizations at all levels and institutions of higher learning to ideological and political work, there is a serious shortage of ideological and political teachers in colleges and universities. Therefore, it is planned to expand the ranks of ideological and political teachers and improve the level of ideological and political teachers in front of colleges and universities.

With the application of information technology and network, teachers and college students can break the boundaries between time and region. It greatly improves the teaching efficiency of ideological and political courses in colleges and universities. However, the network of ideological and political courses inevitably increases the risk that college students are also influenced by the wrong ideas while receiving ideological and political education. The highly virtualized network environment provides fertile soil for cultural innovation and diversification, but also provides a hotbed of [8] for the breeding and spread of wrong ideology and reactionary political forces. So institutions of higher learning must strengthen the construction of prevention and control mechanism, grasp the leadership in the network communication, to deal with the ideological and political class teaching Internet mixed public opinion environment, so the key is to improve the political and political consciousness and theoretical level, to have better discrimination ability, at the same time to master a certain network and information technology.

In view of the phenomenon of order to meet the national requirements between ideological and political teachers and college students and transferring some nonideological and political personnel as ideological and political teachers, first of all, the author is firmly opposed. At the same time, for institutions of higher learning that do this, we believe that at least professional training for these personnel for at least half a year, experienced teachers must be regarded as instructors.

\subsection{Fully Reflect the Students ' Principal Position in the Learning Process of Ideological and Political Courses}

Human nature is the basic concept and requirement of modern education. As the main body of the teaching process, their independence, consciousness and initiative play an important role in the realization of teaching goals. It is the key [8] to give full play to the teaching effect of ideological and political courses in universities to stimulate college students to learn ideological and political courses and enable college students to consciously internalize the Marxist theory into their own ideological, morality and value. Ideological and political class teachers should not only 
attract students to actively participate from the network channels and ideological and political class practice links, but also change the traditional indoctrination teaching way of ideological and political class as the guiding teaching way in the classroom.

\subsection{Realize the Integration of Various Ideological and Political Courses, and Realize the Integrated and Collaborative Teaching}

"We should take the study and implementation of the Party and the Party's innovative theory as the top priority of ideological armament, integrate with the study of the basic principles of Marxism, the history of the Party, the New China, reform and opening up, and the history of socialist development," Xi said. [10]540. Ideological and political courses include: Introduction to the Basic Principles of Marxism, the Outline of Modern Chinese History, Mao Zedong Thought and the Theory of Socialism with Chinese Characteristics, ideological and moral cultivation and legal foundation, and situation and policy. Ideological and political courses itself is a system, and the courses are interdependent, is inseparable Suya Zhou in his paper that the historical trajectory of the CPC of China is an important part of modern history and modern history, closely linked to the teaching content of the "Outline of Modern History", its teaching goal is to help college students deeply understand history and why the people chose Marxism, the Communist Party, socialist road and reform and opening up, precisely because of the "four choices" let the suffering Chinese people and the Chinese nation, find the only way to great rejuvenation [9]. The history of New China is also a historical [9] where Marxism has continuously achieved great victories combined with the reality of China, constantly thinking deeply about the national conditions and the Party, and constantly improving the Party's ruling capacity.

Ideological and political education should not be limited to the introduction of several courses or various indoctrination of ideological and political theories. We must strengthen the mutual integration of each course. We give a curriculum design concept of "Great Ideological and Political Classroom", including the five courses of ideological and political courses, whose logic adopts the "chronological elaboration of + historical events $\rightarrow$ theory" and "chronological + important theory $\rightarrow$ guidance practice" to combine the five courses. For example, we can speak in the outline of modern history of China after the failure of the revolution, the communist party of China armed struggle against the Kuomintang reactionary rule (famous events nanchang uprising), the history of Mao Zedong thought and the theory of socialism with Chinese characteristics of revolutionary army construction and the theory of military strategy, and the basic theory of class and class struggle, the theory of social reform. Based on real, accurate and rich historical materials, with the transformation of time, space and scene, analyze the thoughts, experience and theory of historical figures, guide students to stand in the historical parties ' environment and position to understand and evaluate historical events, is no longer simple and mechanical historical knowledge recitation, but into the historical figures and events, through comparison, analysis and judgment, deepen the understanding of history and theory [7]. Highlight the combination of theory and history, strengthen historical thinking and historical consciousness, and promote the formation of a unified [9] of the political, academic rational, critical, practical and vivid of the educational process.

The implementation of the curriculum of "Great Ideological and Political Classroom" must strengthen the construction of teachers in ideological and political courses, and teachers should achieve "multi-integration". Each teacher should form a "big ideological and political class" teaching group, and each class should set up a topic, and the original courses of their own doors should be integrated into the "big ideological and political class" in the way of collective lesson preparation. Guide students to find problems from a multi-perspective, multi-dimensional, multi-dimensional and all-round way, analyze and think about problems in the "Great Ideological and Political Classroom", so as to affect the formation of students 'values and moral sense. It can also better make students feel the noble personality and profound knowledge of teachers, and consciously become the learning model for college students.

\subsection{Reform the Learning and Assessment Methods}

Strengthen the assessment of the teaching and teaching process of ideological and political courses, and reduce the proportion of the final written test scores. Big data will be applied to the evaluation system of teaching ideological and political courses in colleges and universities, and increase the proportion of students ' online learning behavior, the evaluation of ideological and political course practice, small papers and small reports in the total results. Measure the students' learning situation, learning attitude and learning ability and test results from different dimensions.

\section{CONCLUSIONS}

It is a primary task to cultivate college students' faith, confidence, and trust in Marxism, socialism with Chinese characteristics, and to form a correct world outlook, outlook on life, and values with ideological and political courses in university. In order to make students enjoy ideological and political courses, think carefully about the contents and put it into practice, we must change the current classroom teaching mode into the 
student-centered mode. We must avoid the old cliché and change commonplace teaching ways of separating the theory and practice. Through the application of information technology and ideological and political curriculum integration curriculum design reform, governments at all levels can strengthen the construction of red gene, red education base, strengthen the construction of network platform, to truly realize the students' transformation from passive acceptance of classroom subject to the real understanding and recognition of theory and practice; To truly realize the coordination, unity and integration of various courses.

\section{ACKNOWLEDGMENTS}

Fund Project: 2020 (the first batch) related research results of industry-university cooperative education project of the Ministry of Education No.: 202002050004

\section{REFERENCES}

[1] Jinping $\mathrm{Xi}$, presided over the symposium of teachers ' Ideological and Political Theory [EB/OL]. http://www.gov.cn/xinwen/2019-

03/18/Content_5374831.htm?tdsourcetag=s_pcqq_aiomsg

[2] Jinping Xi, Ideological and Political Course is the key course to implement the fundamental task of cultivating people by virtue [J], Qiushi. 2020, (17), 1 .

[3] Yue Zhang, An Analysis on the Construction and Reform Route of Ideological and Political Courses in Higher Vocational Colleges under the pattern of Great Thinking and Politics ", China Multimedia and Network Teaching Journal, 2021-4-11

[4] Yang Yu, Exploration and Enlightenment of Classroom Teaching Mode of Ideological and Political Theory Courses in Universities in the era of "Internet +", Journal of Hulunbuir College, Volume 29, Issue 2, April 2021.

[5] Jiangyan Ma, innovative research on education system of "Internet + Ideological and Political Science", Volume 34, Volume 9 of Hubei Open Vocational College.

[6] Haitao Liu, Analysis on the Value and Construction of Practical Education under the Vision of Ideological Education, Science and Education Guide 2021 (09), 2021-3-25

[7] Rui Pi, Ideological and Political Teaching in Ideological and Higher Vocational Colleges, Liberal Arts Education, Issue 2, 2021 (Total 884).

[8] Gang Wang, Tianqi, Zou, Innovation Research on Ideological and Political Theory Course at Big
Data University, Jiamusi University Journal of Social Science, Volume 39, Issue 2, April 2021.

[9] Suya Zhou, the "four history" education into the three dimensions of college ideological and political theory courses, ideological education research, April 2021, the 4th total issue 322.

[10] Jinping Xi, on the Governance (Volume 3) P540, [M]. Beijing: Foreign Languages Press, 2020

[11] Lili Fan, Horizontal Comparison: The Main Methods of Ideological and Political Courses Teaching, Journal of Beijing University of Science and Technology (Social Science Edition), April 2021, Volume 37, Issue 2.

[12] Sanbao Liu, Chengyu Xie, Research on Collaborative Innovation of Ideological and Political Education in Colleges and Universities Based on Big Data, Social Science in Guangxi, Issue 4,2021 (Total Issue 310). 